\title{
Determining the bioavailability and toxicity of lead contamination to earthworms requires using a combination of physicochemical and biological methods
}

\author{
Wei Luo ${ }^{\mathrm{a}, \mathrm{b}}$, Rudo A. Verweij ${ }^{\mathrm{b}}$, Cornelis A.M. van Gestel ${ }^{\mathrm{b}, *}$ \\ ${ }^{a}$ State Key Lab of Urban and Regional Ecology, Research Center for Eco-Environmental Sciences, Chinese Academy of Sciences, Beijing 100085, China \\ ${ }^{\mathrm{b}}$ Department of Ecological Science, Faculty of Earth and Life Sciences, VU University, De Boelelaan 1085, 1081 HV Amsterdam, The Netherlands
}

\section{A R T I C L E I N F O}

\section{Article history:}

Received 5 June 2013

Received in revised form

10 October 2013

Accepted 19 October 2013

\section{Keywords:}

Eisenia andrei

Lead

Bioavailability

Toxicity

Shooting range

\begin{abstract}
A B S T R A C T
This study aimed at assessing the bioavailability and toxicity of lead to Eisenia andrei in shooting range soils representing different land uses (forest, grassland, bullet plot). Soils contained $47-2398 \mathrm{mg} \mathrm{Pb} / \mathrm{kg}$ dry weight $(\mathrm{dw})$, but also had different $\mathrm{pH}-\mathrm{CaCl}_{2}$ (3.2-6.8) and organic matter contents (3.8-13\%). Therefore artificial soils with different $\mathrm{pH}$ and organic matter contents and two natural soils were included as control soils. Earthworms were exposed for 28 days and toxicity and uptake of $\mathrm{Pb}$ were related to total, water and $0.01 \mathrm{M} \mathrm{CaCl}_{2}$ extractable and porewater $\mathrm{Pb}$ concentrations as well as to soil characteristics. $\mathrm{Pb}$ uptake in the earthworms linearly increased with increasing soil concentrations. At $>2000 \mathrm{mg} \mathrm{Pb} / \mathrm{kg} \mathrm{dw}$ and $\mathrm{pH}$ 3.3-3.5, high earthworm mortality with significant weight loss and complete inhibition of reproduction were recorded. At $<1000 \mathrm{mg} / \mathrm{kg} \mathrm{dw}$, earthworm reproduction was more related to differences in $\mathrm{pH}$ and other soil characteristics than to $\mathrm{Pb}$.
\end{abstract}

(c) 2013 Elsevier Ltd. All rights reserved.

\section{Introduction}

Shooting ranges around the world represent a significant sink and potential source for trace metal pollution in soil and ground water (Van Vleek et al., 2010). Annual lead (Pb) loadings of up to six tonnes were reported on three Danish shooting ranges (Jorgensen and Willems, 1987). In Finland, a survey identified more than 2000 outdoor shooting ranges, both military and civilian, with an estimated annual deposit of approximately $500 \mathrm{~kg} \mathrm{~Pb}$ per range (Sorvari et al., 2006). In Switzerland, more than 2000 shooting ranges are used for the regular shooting practice of civilian militia and sports (Mozafar et al., 2002) resulting in an annual deposition of more than $400 \mathrm{t}$ of $\mathrm{Pb}$ into soils (Johnson et al., 2005; Robinson et al., 2008). Approximately $100 \mathrm{t} \mathrm{Pb}$ used by the Norwegian armed forces were deposited in Norwegian shooting ranges from small arms ammunition (Heier et al., 2010). In the United States, $60,000 \mathrm{t}$ of $\mathrm{Pb}$ is being deposited each year in shooting range soils (Ahmad et al., 2011). Lead accounting for 95-97\% of the bullet material at shooting ranges (Cao et al., 2003) is of increasing concern in many countries (Lin, 1996; Sorvari, 2007) since it is known to be hazardous to human and environmental health.

\footnotetext{
* Corresponding author.

E-mail addresses: kees.van.gestel@falw.vu.nl, kees.van.gestel@vu.nl (C.A.M. van Gestel).
}

Therefore, the United State Environmental Protection Agency has classified $\mathrm{Pb}$ residues in shooting range soils as hazardous materials (USEPA, 2001).

Shooting ranges increase the ecotoxicological risks for the surrounding environment by contaminating soils, surface water, ground water, terrestrial, and aquatic biota. Soil invertebrates, birds, and other animals may ingest this soil while foraging for food. Earthworms play an important role in soil ecosystems because of their role in soil structuring and decomposition processes. They are particularly prone to accumulating metals to much higher levels than in the environment (Morgan et al., 1993) and therefore may play a key role in the food chain transfer of metals from soil to higher organisms. The literature shows a lack of consensus on the toxicity of $\mathrm{Pb}$ to earthworms, with enhancement of reproduction at 1000 and 2000 mg Pb/kg (Reinecke and Reinecke, 1996; Reinecke et al., 1997), no observed effects on reproduction at $1810 \mathrm{mg} \mathrm{Pb} /$ $\mathrm{kg}$ and a significant reduction in cocoon production at $2000 \mathrm{mg} \mathrm{Pb} /$ $\mathrm{kg}$ (Spurgeon et al., 1994). Data on Pb uptake in earthworms show striking differences with $\mathrm{Pb}$ body burdens of $75.6 \pm 46 \mathrm{mg} / \mathrm{kg}$ in Lumbricus castaneus collected from soil containing 412 to 79,963 mg Pb/kg (Terhivuo et al., 1994), and $348 \pm 72 \mathrm{mg} \mathrm{Pb} / \mathrm{kg}$ in L. castaneus exposed to soil containing only $200 \mathrm{mg} \mathrm{Pb} / \mathrm{kg}$ (Svendsen et al., 1996).

Kabata-Pendias and Pendias (1992) concluded that Pb concentration in the soil solution is a better indicator of adverse effects on 
biota than total soil $\mathrm{Pb}$ levels, with metal ions determining toxicity (Smolders et al., 2009). In contrast, Davies (1992), Grelle and Descamps (1998) and Booth et al. (2003) found that Pb uptake in plants and earthworms was predicted best using total soil $\mathrm{Pb}$ concentrations. The majority of metals in natural soils at contaminated sites will be present as solids which are not bioavailable (Davies et al., 2003b). As a consequence, metal toxicity is generally less pronounced in metal-contaminated field soils than in soils freshly spiked with metal salts at similar total metal concentrations (Lock et al., 2006). It is difficult to interpret toxicological parameters derived from field studies due to co-contamination and variations in soil properties. However, results obtained are more applicable to a contaminated site because they represent realistic conditions at that site compared with using spiked artificial or uncontaminated field soils (Nahmani et al., 2007).

A variety of extraction procedures have been suggested for predicting the bioavailability of $\mathrm{Pb}$ in different soils, but results are inconsistent (Cook and Hendershot, 1996). Often total metal concentrations are used, taking for granted that environmental risk assessment based on the total concentrations can overestimate risks, and that organisms respond only to the fraction that is biologically available (Alexander, 2000; Ehlers and Luthy, 2003; Semple et al., 2004). Methods to assess available metal concentrations often use extraction with water or a dilute salt solution, but question is: do they really predict "biological availability"? The only way to answer that question is by comparing the results of chemical extractions with effects on organisms, preferably with simple, costand time-effective bioassays, covering a variety of effects across different taxa (Harmsen, 2007; Antunes et al., 2008). The combination of chemical and biological tests may provide more complete and relevant information on the bioavailability of contaminants (Van Gestel et al., 2001; Loureiro et al., 2005; Antunes et al., 2008; Alvarenga et al., 2012; Van Gestel et al., 2012). Also, the properties of the soil need to be considered when interpreting the results of tests with earthworms. Although not feasible in practice, the results of a site assessment would be more reliable if a control would be available that "mimics" the contaminated test soil in all aspects except for the contaminants being present (Alvarenga et al., 2012).

The present paper is part of a broader study that aimed at linking chemical and biological measures of $\mathrm{Pb}$ bioavailability in shooting range soils with different land uses (forest, grassland, bullet plot), containing different concentrations of $\mathrm{Pb}(47-2398 \mathrm{mg}$ $\mathrm{Pb} / \mathrm{kg} \mathrm{dw}$ ). Soils were tested for toxicity to earthworms and other soil invertebrates applying a combination of physico-chemical and biological assays. Since the field soils also differed in $\mathrm{pH}-\mathrm{CaCl}_{2}$ (3.26.8 ) and organic matter contents (3.8-13\%), differently prepared artificial soils and two natural soils (soccer field soil, LUFA 2.2) were used as control soils. This paper focuses on the tests done with earthworms. Toxicity and uptake of $\mathrm{Pb}$ in the earthworms were related with total, water and $0.01 \mathrm{M} \mathrm{CaCl}_{2}$ extractable and porewater $\mathrm{Pb}$ concentrations in soils as well as with soil properties.

\section{Materials and methods}

\subsection{Sampling and experiment design}

Field soils were collected from five different sites representative of different landscape types (F: forest; G: grassland; B: bullet plot) in a shooting range and a reference site (S: soccer field near the shooting range) in the Netherlands. At each site, a square zone $(25 \times 25 \mathrm{~m})$ divided with grid pattern $(5 \times 5 \mathrm{~m})$ was established. A total of 10 soil samples were collected from the cross line of the zone, using a cylindrical soil corer to a depth of $20 \mathrm{~cm}$. The 10 samples from each site were pooled and mixed thoroughly to give one representative sample for each site. Three artificial soils (R1, R2 and R3) were prepared, based on OECD artificial soil (OECD, 1984). $\mathrm{R} 1$, the standard artificial soil, was prepared by mixing $10 \%$ finely ground sphagnum peat ( $<1 \mathrm{~mm}$ ), 20\% kaolin clay, and $70 \%$ quartz sand (dry weight), adjusted with $\mathrm{CaCO}_{3}$ to nominal $\mathrm{pH}-\mathrm{CaCl}_{2} 6.0 \pm 0.5$. The other two artificial soils were prepared with peat contents of $5 \%$ (R2) or $2.5 \%$ (R3) and $\mathrm{pH}-\mathrm{CaCl}_{2}$ adjusted to nominal 3.5 (R2) or 6.5 (R3) with $\mathrm{CaCO}_{3}$ (Table 1). The standard LUFA 2.2 soil (LUFA-Speyer, Sp 2121, Germany) was used as a control (LF2.2).

\subsection{Physico-chemical analysis}

The soil samples were air dried, homogenised and $2 \mathrm{~mm}$ sieved. All soils were characterized for their cation exchange capacity (CEC) using the silver thiourea method (Dohrmann, 2006). Exchangeable cations in extracts were determined by flame atomic absorption spectroscopy (AAS; Perkin Elmer, Analyst 100). Organic matter content of the soils was determined as loss on ignition at $500{ }^{\circ} \mathrm{C}$ in an ashing oven. The organic carbon content (\% OC) was determined by dividing the organic matter content by the Van Bemmelen factor (1.724; Howard and Howard, 1990). Water holding capacity (WHC) of the soils was determined by the sandbox method (ISO, 1999). Particle size distribution was determined by laser grain size analysis with laser diffraction sensors (HELOS-QUIXEL) (Konert and Vandenberghe, 1997).

To assess available $\mathrm{Pb}$ concentrations, soils were extracted with water and $0.01 \mathrm{M} \mathrm{CaCl}_{2}$ (Houba et al., 1996), while also porewater was extracted. Water and $\mathrm{CaCl}_{2}$ extraction are typically used to estimate metal bioavailability and may correlate with metal availability to earthworms (Davies et al., 2003b). Dried soil ( $5 \mathrm{~g}$ ) was shaken with distilled water $(25 \mathrm{~mL})$ or $0.01 \mathrm{M} \mathrm{CaCl}_{2}(25 \mathrm{~mL})$ for $2 \mathrm{~h}$ at $200 \mathrm{rpm}$. After sedimentation $\mathrm{pH}$ was measured in the extracts using a Consort $\mathrm{P} 907 \mathrm{pH}$ meter. After filtration ( $\& \& S, 0.45 \mu \mathrm{m}$, Ø $47 \mathrm{~mm}$ ), solutions were used to measure water and $\mathrm{CaCl}_{2}$ extractable $\mathrm{Pb}$ concentrations. After saturation of the soils to $100 \%$ WHC and 1 week equilibration, porewater was collected by the double-chamber centrifugation method and filtration through a $0.45 \mu \mathrm{m}$ membrane filter (Hobbelen et al., 2004). Immediately after centrifugation at $2056 \mathrm{~g}$, solutions were analysed for $\mathrm{Pb}$ and dissolved organic carbon (DOC). To determine total $\mathrm{Pb}, \mathrm{Cu}, \mathrm{Zn}$, $\mathrm{Cd}, \mathrm{Ca}$ and Fe concentrations, approx. $0.1 \mathrm{~g}$ oven-dried soil samples were digested in $2 \mathrm{~mL}$ of a 4:1 mixture of nitric acid (65\% p.a.; Riedel-de-Haen) and hydrochloric acid (37\% p.a., Baker) in tightly closed Teflon ${ }^{\circledR}$ bombs upon heating in a destruction oven at $140{ }^{\circ} \mathrm{C}$ for $7 \mathrm{~h}$. After cooling, the samples were made up to $10 \mathrm{~mL}$ with NANO pure water. Flame AAS (Perkin-Elmer, Analyst 100) was used to determine metal concentrations. DOC was measured by a TOC analyzer (SK ${ }^{12}$ Skalar, Breda, The Netherlands). A certified reference soil (International Soil-Analytical Exchange, ISE sample 989) was included to control quality of the analysis. Satisfactory recoveries in triplicate analysis (mean $\pm \mathrm{SD}$ ) were obtained for $\mathrm{Pb}(93 \pm 4 \%$ ), $\mathrm{Cd}(89 \pm 0 \%), \mathrm{Zn}$ $(83 \pm 1 \%)$ and $\mathrm{Cu}(107 \pm 2 \%), \mathrm{Ca}(86 \pm 2 \%)$ and $\mathrm{Fe}(93 \pm 3 \%)$. Porewater $\mathrm{Pb}$ concentrations below the detection limit $(0.018 \mathrm{mg} / \mathrm{L})$ were set at the detection limit divided by two $(0.009 \mathrm{mg} / \mathrm{L})$.

\subsection{Toxicity and bioaccumulation test}

Eisenia andrei (Lumbricidae) were obtained from a laboratory culture at the Department of Ecological Science, VU University, Amsterdam. Earthworms were cultured in horse manure free of any pharmaceuticals at $20 \pm 1{ }^{\circ} \mathrm{C}$. Before the start of the experiment, adult earthworms with well-developed clitellum (individual mass range 333-794 mg) were acclimatized in LF2.2 soil for $24 \mathrm{~h}$. The tests with earthworms followed OECD guideline 222 for determining reproduction toxicity of chemicals to earthworms (OECD, 2004). Each test soil was moistened to $50 \%$ of its WHC. Each toxicity test had five replicate test containers containing approx. $500 \mathrm{~g}$ soil (dry weight equivalent). At the start of the test, each batch of 10 animals was weighed and randomly assigned to a test container. After introduction of the earthworms, $5 \mathrm{~g}$ (dry weight) finely ground and moistened horse dung was introduced as a food source in a hole in the middle of the test soil following Van Gestel et al. (1989). Test containers were incubated at $20^{\circ} \mathrm{C}$, and constant illumination. Once a week all test containers were opened to aerate the test soils, correct for water loss and add additional food if required. After 4 weeks, surviving adults were collected by hand sorting, counted and weighed. The soils were incubated for another 4 weeks to allow the cocoons to hatch. After the second 4 -week period, juveniles were extracted by placing the test containers in a water bath at $60^{\circ} \mathrm{C}$.

Surviving adult earthworms were kept on moist filter paper for approx. $24 \mathrm{~h}$ to void their gut contents, following Arnold and Hodson (2007), and then frozen, freeze-dried for $2 \mathrm{~d}$ and weighed. Wet weights of each earthworm were measured and recorded both before and after depuration. Day 28 weights (before depuration) were compared with weights recorded on day 0 to provide an additional measure of toxicity. Weight loss (WL, \%) of earthworms was calculated using the equation:

$\mathrm{WL}=\left(\left(W_{\mathrm{i}}-W_{\mathrm{s}}\right) / W_{\mathrm{i}}\right) \times 100$

in which $W_{\mathrm{i}}$ is initial mean earthworm weight, and $W_{\mathrm{s}}$ is mean weight of surviving earthworms after 28 days of exposure.

Five replicate animals were collected from each replicate test soil except for F1 $(n=4)$ and analysed to obtain $\mathrm{Pb}$ concentrations in body issues. Dried earthworms were digested using the same acid mixture and Teflon bombs as described for soil samples. The digests were then analysed by flame AAS (Perkin Elmer, Analyst 100). The limit of detection for $\mathrm{Pb}$ in earthworm tissues was $4 \mathrm{mg} / \mathrm{kg}$ dry weight. All tissue analyses included procedural blanks and a certified reference material (Dolt-2) conducted in triplicate. Digested blanks contained $\mathrm{Pb}$ concentrations below the limit of detection. Recovery of $\mathrm{Pb}$ from the Dolt-2 in triplicate analysis (mean $\pm \mathrm{SD}$ ) was $97 \pm 2.8 \%$. 
Table 1

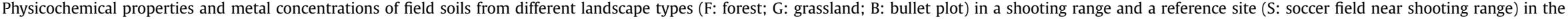
Netherlands and artificial soils (R) as well as a control (LF2.2: LUFA 2.2) used for assessing the toxicity and bioaccumulation of lead in Eisenia andrei. All values are averages with standard deviation ( $n=3$ ).

\begin{tabular}{|c|c|c|c|c|c|c|c|c|c|c|c|}
\hline & \multicolumn{7}{|l|}{ Field soil } & \multicolumn{3}{|l|}{ Artificial soil } & \multirow{2}{*}{$\frac{\text { Control }}{\text { LF2.2 }}$} \\
\hline & B0 & F0 & $\mathrm{F} 1$ & F3 & G1 & G3 & S & R1 & R2 & R3 & \\
\hline $\mathrm{pH}-\mathrm{H}_{2} \mathrm{O}$ & $4.2 \pm 0.11 \mathrm{~b}$ & $3.9 \pm 0.0058 \mathrm{a}$ & $4.0 \pm 0.025 \mathrm{a}$ & $4.2 \pm 0.021 \mathrm{~b}$ & $7.5 \pm 0.021 \mathrm{f}$ & $6.9 \pm 0.0071 \mathrm{e}$ & $6.9 \pm 0.014 \mathrm{e}$ & $5.9 \pm 0.026 \mathrm{~d}$ & $4.6 \pm 0.012 c$ & $6.8 \pm 0.040 \mathrm{e}$ & $6.0 \pm 0.021 \mathrm{~d}$ \\
\hline $\begin{array}{c}\mathrm{pH}-0.01 \mathrm{M} \\
\mathrm{CaCl}_{2}\end{array}$ & $3.7 \pm 0.014 \mathrm{c}$ & $3.2 \pm 0.012 \mathrm{a}$ & $3.3 \pm 0.00 \mathrm{a}$ & $3.5 \pm 0.014 \mathrm{~b}$ & $6.8 \pm 0.071 \mathrm{~g}$ & $6.5 \pm 0.0071 \mathrm{f}$ & $6.8 \pm 0.00 \mathrm{~g}$ & $5.9 \pm 0.040 \mathrm{e}$ & $3.8 \pm 0.042 c$ & $6.4 \pm 0.070 \mathrm{f}$ & $5.5 \pm 0.010 \mathrm{~d}$ \\
\hline WHC (\%) & $33 \pm 0.26 \mathrm{a}$ & $50 \pm 1.1 \mathrm{f}$ & $49 \pm 0.52$ def & $44 \pm 0.017 c$ & $40 \pm 0.76 b$ & $49 \pm 0.31$ ef & $62 \pm 0.42 \mathrm{~g}$ & $77 \pm 2.0 \mathrm{~h}$ & $39 \pm 0.83 \mathrm{~b}$ & $35 \pm 0.10 \mathrm{a}$ & $45 \pm 0.75$ cde \\
\hline \%Clay $(<8 \mu \mathrm{m})^{\mathrm{a}}$ & $2.7 \pm 1.6 \mathrm{a}$ & $4.2 \pm 1.8 \mathrm{abc}$ & $4.5 \pm 1.8 \mathrm{abc}$ & $5.9 \pm 2.0 \mathrm{bc}$ & $3.5 \pm 1.8 \mathrm{ab}$ & $10 \pm 2.4 \mathrm{de}$ & $7.5 \pm 2.1 \mathrm{~cd}$ & $18.6 \pm 2.5 \mathrm{f}$ & $25.5 \pm 2.7 \mathrm{~g}$ & $27.1 \pm 2.8 \mathrm{~g}$ & $12.2 \pm 2.5 \mathrm{e}$ \\
\hline$\%$ Silt $(8-63 \mu \mathrm{m})$ & $6.9 \pm 1.6 \mathrm{a}$ & $13.3 \pm 1.8 \mathrm{c}$ & $12.1 \pm 1.8 \mathrm{~b}$ & $12.2 \pm 2.0 \mathrm{~b}$ & $10.6 \pm 1.8 \mathrm{~b}$ & $23 \pm 2.4 \mathrm{~d}$ & $11.8 \pm 2.1 \mathrm{~b}$ & $19.8 \pm 2.5 \mathrm{c}$ & $22.2 \pm 2.7 \mathrm{~cd}$ & $23 \pm 2.8 \mathrm{~d}$ & $13.3 \pm 2.5 \mathrm{~b}$ \\
\hline $\begin{array}{l}\text { \%Sand } \\
\qquad(63-2000 \\
\mu \mathrm{m})\end{array}$ & $90.5 \pm 1.6 \mathrm{e}$ & $82.5 \pm 1.8$ cde & $83.4 \pm 1.8$ cde & $81.9 \pm 2.0$ cde & $85.9 \pm 1.8 \mathrm{de}$ & $67 \pm 2.4 \mathrm{~b}$ & $80.7 \pm 2.1 \mathrm{~cd}$ & $61.6 \pm 2.5 \mathrm{~b}$ & $52.3 \pm 2.7 \mathrm{a}$ & $49.9 \pm 2.8 \mathrm{a}$ & $74.5 \pm 2.5 \mathrm{bc}$ \\
\hline OM (\% LOI) & $3.8 \pm 0.12 \mathrm{~b}$ & $7.0 \pm 0.080 \mathrm{~d}$ & $5.8 \pm 0.078 c$ & $6.6 \pm 0.13 \mathrm{~d}$ & $4.1 \pm 0.095 \mathrm{~b}$ & $5.3 \pm 0.012 c$ & $13 \pm 0.53 \mathrm{f}$ & $8.8 \pm 0.25 \mathrm{e}$ & $4.5 \pm 0.10 \mathrm{~b}$ & $2.4 \pm 0.069 \mathrm{a}$ & $4.3 \pm 0.090 \mathrm{~b}$ \\
\hline CEC $(\mathrm{cmolc} / \mathrm{kg})$ & $1.8 \pm 0.088 \mathrm{a}$ & $2.1 \pm 0.00071 \mathrm{a}$ & $2.1 \pm 0.092 \mathrm{a}$ & $2.1 \pm 0.11 \mathrm{a}$ & $5.9 \pm 0.076 \mathrm{~b}$ & $13 \pm 1.8 \mathrm{~d}$ & $21 \pm 0.37 \mathrm{e}$ & $12 \pm 0.55 \mathrm{~d}$ & $2.8 \pm 0.031 \mathrm{a}$ & $3.9 \pm 0.027 \mathrm{ab}$ & $8.9 \pm 0.61 c$ \\
\hline $\mathrm{DOC}(\mathrm{mg} / \mathrm{L})$ & $703 \pm 23 \mathrm{e}$ & $984 \pm 26 \mathrm{f}$ & $651 \pm 4.7 \mathrm{cde}$ & $693 \pm 26 \mathrm{de}$ & $183 \pm 4.7 \mathrm{a}$ & $519 \pm 0.46 \mathrm{bc}$ & $673 \pm 116 \mathrm{cde}$ & $945 \pm 9.4 \mathrm{f}$ & $543 \pm 31 \mathrm{bcd}$ & $424 \pm 4.6 \mathrm{~b}$ & $889 \pm 15 \mathrm{f}$ \\
\hline $\begin{array}{l}\text { Total Ca } \\
\qquad(\mathrm{mg} / \mathrm{kg}, \mathrm{dw})\end{array}$ & $99 \pm 12 \mathrm{a}$ & $87 \pm 27 a$ & $130 \pm 10 \mathrm{ab}$ & $91 \pm 20 \mathrm{a}$ & $1179 \pm 39 \mathrm{de}$ & $1331 \pm 254 \mathrm{e}$ & $2467 \pm 10 \mathrm{f}$ & $1082 \pm 4.6 \mathrm{de}$ & $213 \pm 7.5 \mathrm{~b}$ & $495 \pm 40 \mathrm{c}$ & $761 \pm 17 \mathrm{~cd}$ \\
\hline $\begin{array}{l}\text { Total Fe } \\
\quad(\mathrm{mg} / \mathrm{kg}, \mathrm{dw})\end{array}$ & $3332 \pm 56 b$ & $5644 \pm 1728 b$ & $4430 \pm 214$ bc & $7703 \pm 2170 \mathrm{c}$ & $4061 \pm 259$ bc & $10,565 \pm 910 \mathrm{~d}$ & $11,890 \pm 5004 \mathrm{~d}$ & $596 \pm 28 \mathrm{a}$ & $477 \pm 5.6 \mathrm{a}$ & $497 \pm 5.0 \mathrm{a}$ & $4313 \pm 93 b$ \\
\hline $\begin{array}{l}\text { Total Pb } \\
\quad(\mathrm{mg} / \mathrm{kg}, \mathrm{dw})\end{array}$ & $88 \pm 9.0 \mathrm{~b}$ & $47 \pm 9.7 \mathrm{ab}$ & $2153 \pm 0.0 \mathrm{e}$ & $2398 \pm 311 \mathrm{e}$ & $656 \pm 60 \mathrm{~d}$ & $355 \pm 54 \mathrm{c}$ & $36 \pm 1.4 \mathrm{ab}$ & $42 \pm 2.1 \mathrm{ab}$ & $45 \pm 0.0 \mathrm{ab}$ & $50 \pm 1.4 \mathrm{ab}$ & $15 \pm 0.71 \mathrm{a}$ \\
\hline $\begin{array}{l}\text { Total Cd } \\
\quad(\mathrm{mg} / \mathrm{kg}, \mathrm{dw})\end{array}$ & $0.12 \pm 0.042 \mathrm{abc}$ & $0.10 \pm 0.011 a b c$ & $0.091 \pm 0.0078 \mathrm{abc}$ & $0.068 \pm 0.040 a b$ & $0.15 \pm 0.00071 \mathrm{bc}$ & $0.29 \pm 0.071 \mathrm{c}$ & $0.19 \pm 0.058 b c$ & $0.021 \pm 0 \mathrm{a}$ & $0.095 \pm 0 \mathrm{abc}$ & $0.057 \pm 0.052 \mathrm{ab}$ & $0.20 \pm 0.055 b c$ \\
\hline $\begin{array}{l}\text { Total Zn } \\
\quad(\mathrm{mg} / \mathrm{kg}, \mathrm{dw})\end{array}$ & $5.7 \pm 0.071 \mathrm{~b}$ & $7.4 \pm 2.3 \mathrm{bc}$ & $7.1 \pm 0.071 \mathrm{bc}$ & $8.9 \pm 0.98 c$ & $14 \pm 0.64 \mathrm{~d}$ & $59 \pm 3.8 \mathrm{~g}$ & $37 \pm 0.14 \mathrm{f}$ & $3.8 \pm 0.28 \mathrm{a}$ & $3.0 \pm 0.071 \mathrm{a}$ & $3.2 \pm 0.071 \mathrm{a}$ & $21 \pm 0.64 \mathrm{e}$ \\
\hline $\begin{array}{l}\text { Total } \mathrm{Cu} \\
\qquad(\mathrm{mg} / \mathrm{kg}, \mathrm{dw})\end{array}$ & $1.2 \pm 0.071 \mathrm{~b}$ & $2.4 \pm 0.42 \mathrm{~cd}$ & $3.0 \pm 0.071 \mathrm{~cd}$ & $1.9 \pm 0.38 \mathrm{c}$ & $8.4 \pm 0.35 \mathrm{e}$ & $15 \pm 2.5 \mathrm{f}$ & $12 \pm 0.35$ ef & $0.35 \pm 0.071 \mathrm{a}$ & $0.55 \pm 0.071 \mathrm{a}$ & $0.50 \pm 0 \mathrm{a}$ & $3.6 \pm 0.28 \mathrm{~d}$ \\
\hline
\end{tabular}

WHC = Water holding capacity; OM = , Organic matter; CEC = Cation exchange capability; DOC $=$ Dissolved oxygen carbon in porewater.

The same letter indicate no significant differences at $p>0.05$, using. a post-hoc Tukey HSD test.

a The fraction $<8 \mu \mathrm{m}$ determined with the method of Konert and Vandenberghe (1997) corresponds with the clay fraction $<2 \mu \mathrm{m}$. 


\subsection{Statistical analysis}

LC50s (concentration causing 50\% mortality) for the effect of $\mathrm{Pb}$ on earthworm survival were calculated using the trimmed Spearman-Karber method (Hamilton et al., 1977). EC10 and EC50 values and corresponding 95\% confidence intervals for effects on reproduction were estimated with the log-logistic model of Haanstra et al. (1985), applying the modification described by Van Brummelen et al. (1996).

All metal concentrations, but not soil physicochemical properties and bioassay values were log-transformed before analysis to satisfy assumptions of normality. All data were checked for homogeneity of variance and normality (KolmogorovSmirnov test) and, when possible, subjected to one-way ANOVA. When significant differences were found $(p<0.05)$ a post-hoc Tukey HSD test was used to further elucidate differences among means $(p<0.05)$. Pearson's correlation coefficients $(r)$ were calculated between toxicity data and soil physicochemical properties $(p<0.05)$. To determine the relative importance of the different soil characteristics contributing to soil $\mathrm{Pb}$ toxicity and to examine the relationship between each earthworm bioassay endpoint and the combined soil properties, multiple linear regression models were constructed.

Except for the trimmed Spearman-Karber calculations, all analyses were run in the software package SPSS15.0 for Windows.

\section{Results and discussion}

\subsection{Physicochemical characterization of soils}

Physicochemical characteristics of the field and artificial soils are summarized in Table 1. Among the soils studied, forest soils, especially F1 and F2, had the lowest pH, while grassland soil had the highest $\mathrm{pH}$. Most $\mathrm{pH}-\mathrm{CaCl}_{2}$ values except for soil $\mathrm{G} 1$ fell within the tolerable pH range of Eisenia andrei (4.0-7.5) (Edwards, 1988;
Edwards and Bohlen, 1996). The soccer field soil had the highest and the bullet plot soil the lowest organic matter content. The forest soils also had higher DOC concentrations in the porewater than the grassland, while DOC level in soccer field soil was significantly lower and in bullet plot soil significantly higher compared to the other soils. Most field soils had lower clay content than the LF2.2 control soil. Bullet plot soil had the lowest clay content. Soil G3 had the highest silt content, bullet plot soil the lowest. Bullet plot soils had highest sand content. The soccer field soil had the highest CEC, the bullet plot soil the lowest CEC. Ca concentrations were similar in forest and bullet plot soils, but higher in grassland and soccer field soils. Fe concentrations were highest in G3 and S and did not differ much for the other field soils. Total $\mathrm{Cu}, \mathrm{Zn}$ and $\mathrm{Cd}$ concentrations were well within the range of the background levels in Dutch soils ( $\mathrm{Cd}=0.5-0.6 \mathrm{mg} / \mathrm{kg} ; \mathrm{Cu}=18-21 \mathrm{mg} / \mathrm{kg} ; \mathrm{Zn}=60-$ $70 \mathrm{mg} / \mathrm{kg}$ ) (Vegter, 1995).

\subsection{Availability of $\mathrm{Pb}$ in the soils}

Total and available $\mathrm{Pb}$ concentrations in all test soils are shown in Fig. 1. Soils F1 and F3 had the highest total, $\mathrm{CaCl}_{2}$ and water extractable as well as porewater Pb concentrations. Soils G1 and G3 had higher total but lower $\mathrm{CaCl}_{2}$ extractable $\mathrm{Pb}$ concentrations than the bullet plot soil. Although soil $\mathrm{B} 0$ had similar total, $\mathrm{CaCl}_{2}$ extractable and porewater $\mathrm{Pb}$ concentrations than $\mathrm{F} 0$, its water extractable $\mathrm{Pb}$ was remarkably higher than that in F0. Based on the
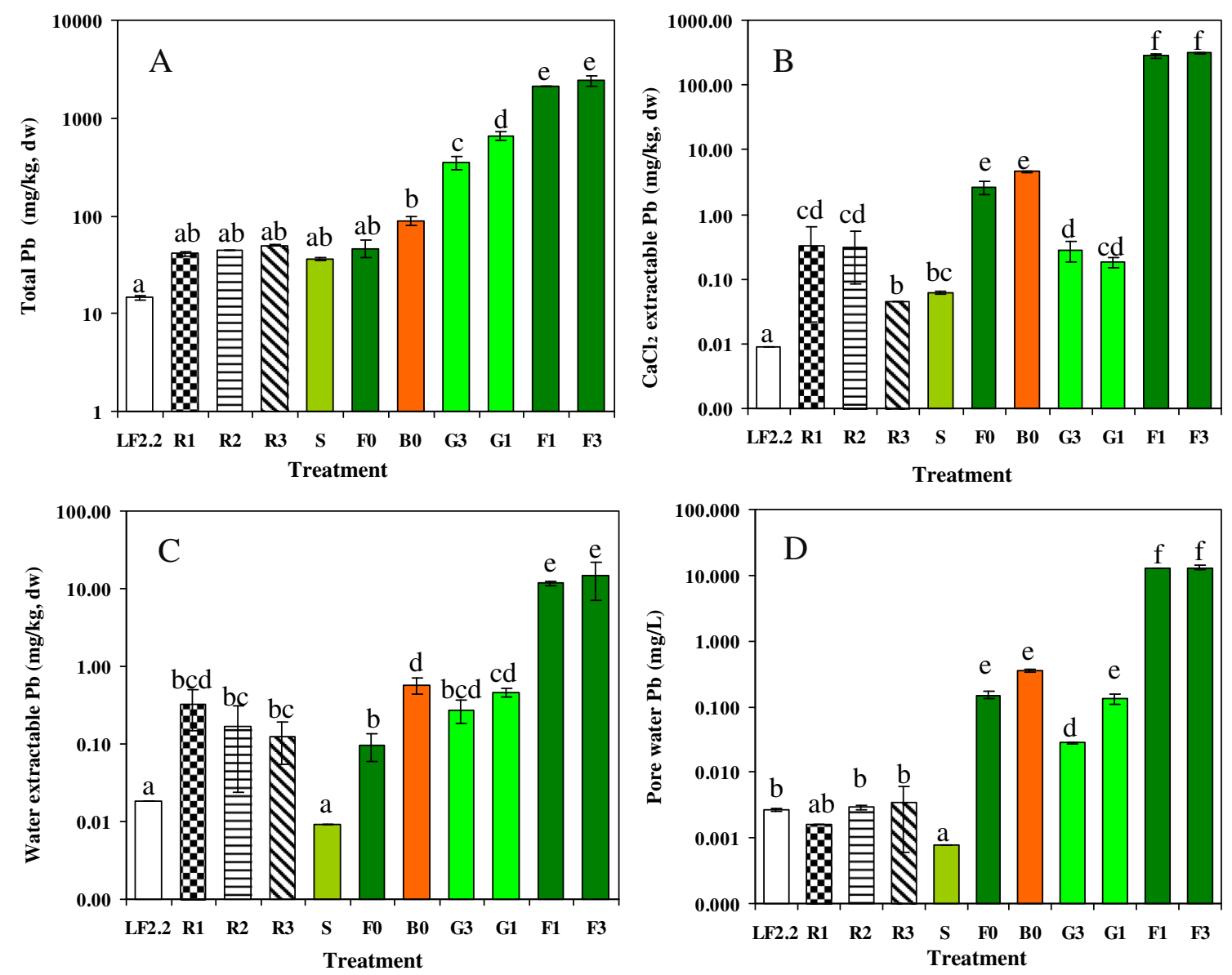

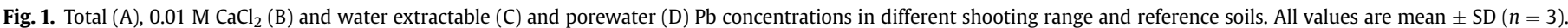

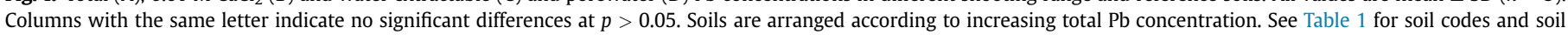
properties. 

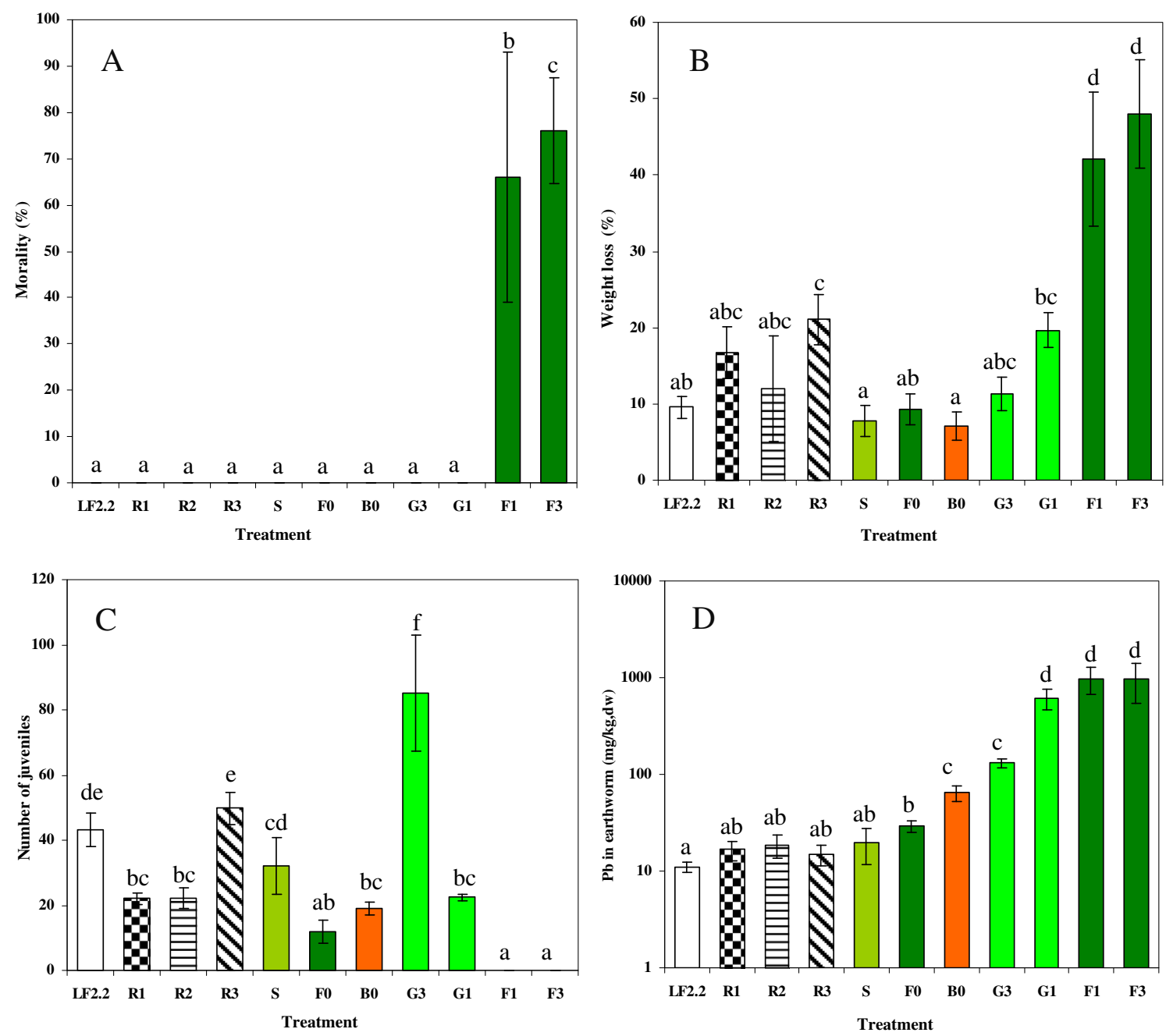

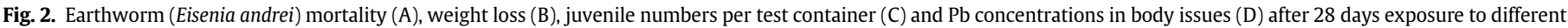

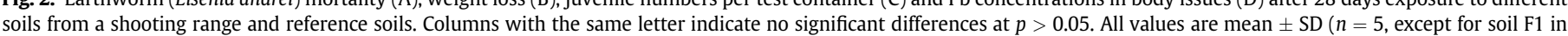

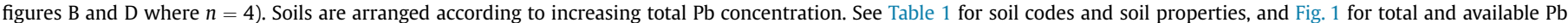
concentrations in these soils.

background levels of $\mathrm{Pb}$ in Dutch soils (Vegter, 1995), except for site F0, all shooting field soils were contaminated by $\mathrm{Pb}$.

In our study, water extracted the least $\mathrm{Pb}$ with a maximum of about $1 \%$ of the total lead which is in agreement with previous results (Houba et al., 1996; Quevauviller, 1998). $\mathrm{CaCl}_{2}$ extracted the highest amount of $\mathrm{Pb}$ with a maximum of about $10 \%$ of the total concentration (Fig. 1B), which was higher than the value of $1 \%$ reported by Davies et al. (2003a) and Singh et al. (1996), reflecting the higher availability of $\mathrm{Pb}$ in the shooting field soils. This high $\mathrm{Pb}$ availability in soils F1 and F3 may be explained from their low pH (Basta and Tabatabai, 1992; Rieuwerts et al., 2006; Farrah and Pickering, 1979). As a result of their high $\mathrm{pH}, \mathrm{CaCl}_{2}$, water extractable and porewater $\mathrm{Pb}$ concentrations were relatively low despite of relatively high total $\mathrm{Pb}$ concentrations in the grassland soils $\mathrm{G} 1$ and G3, while the opposite was seen for the acid soils F0 and B0. So the high extractability of $\mathrm{Pb}$ in $\mathrm{F} 1$ and $\mathrm{F} 3$ was not only because of their high total $\mathrm{Pb}$ concentrations but also due to their lower $\mathrm{pH}$ values. Also the presence of organic matter may have influenced extractability (Rieuwerts et al., 2006). Soluble organo-Pb complexes may be formed at the high DOC contents in the forest soils. So, extractability of $\mathrm{Pb}$ in soil F0 was remarkably high as a result of its high organic matter and DOC contents, even though it had a relatively low total $\mathrm{Pb}$ concentration.

\subsection{Toxicity and bioaccumulation of lead in earthworms}

After 28 days of exposure, high mortality of adult $E$. andrei was seen in the two most polluted soils F3 (76 $\pm 11 \%)$ and F1 ( $66 \pm 27 \%$ ), while no mortality occurred in the other soils (Fig. 2A). Significant earthworm mortality was first seen at concentrations of 2153 and $2398 \mathrm{mg} / \mathrm{kg}$ total $\mathrm{Pb}$. Significant weight loss of the earthworms after 28 days of exposure occurred in the two most polluted soils where also high mortality was recorded (Fig. 2B). Weight loss of E. andrei was lowest in the soils S, F0, B0 and G3. Growth has been proposed as a sensitive indicator of exposure to contaminants (Langdon et al., 2005). Weight loss of the adult earthworms was not significantly affected at soil $\mathrm{Pb}$ concentrations up to $656 \mathrm{mg} / \mathrm{kg} \mathrm{dw}$. However, our study confirmed Emersen's suggestion (Emersen, 1994) that lead contamination at shooting ranges (for example F1 and F3) may significantly affect earthworm growth, and therefore might potentially impact on earthworm populations.

The numbers of juveniles produced were lower in soils F0, B0 and G1 than in the control soil LF2.2. No juveniles were produced in the most contaminated soils F1 and F3, while soil G3 had the highest juvenile numbers (Fig. 2C). At total $\mathrm{Pb}$ concentrations up to $656 \mathrm{mg} / \mathrm{kg} \mathrm{dw}$ E. andrei reproduction was not affected; this 
corresponded with porewater $\mathrm{Pb}$ concentrations $<0.028 \mathrm{mg} / \mathrm{L}$. Artificial soils R1 and R2 had similar numbers of juveniles, but significantly less than the soils LF2.2 and R3, which means that a soil $\mathrm{pH}$ lower than 5.9 may significantly reduce juvenile numbers. Compared to LF2.2, high concentrations of $\mathrm{Pb}(>2000 \mathrm{mg} / \mathrm{kg} \mathrm{dw})$ in soils did inhibit earthworm reproduction although it also has to be noted that the most contaminated soils had a low $\mathrm{pH}-\mathrm{CaCl}_{2}$ (3.3-3.5). Spurgeon et al. (1994) did observe a significant reduction in the cocoon production of Eisenia fetida at $2000 \mathrm{mg} \mathrm{Pb} / \mathrm{kg}$ in artificial soils prepared following OECD guideline No. 207 (OECD, 1984).

The concentration of lead in the earthworms did not increase significantly until soil concentrations of $88 \pm 9.0 \mathrm{mg} \mathrm{Pb} / \mathrm{kg} \mathrm{dw}$ (Fig. 2D). At higher total soil $\mathrm{Pb}$ concentrations earthworm concentrations increased in a dose-related manner. The greater availability of $\mathrm{Pb}$ in the most-contaminated soils F1 and F3 was reflected by higher uptake ( $980 \mathrm{mg} / \mathrm{kg} \mathrm{dw}$ ) and also higher mortality and weight loss and lower juvenile numbers (Fig. 2A-C).

Although different factors affected $\mathrm{Pb}$ toxicity in the test soils, we did try to calculate LC50, EC50 and EC10 values for the toxicity of $\mathrm{Pb}$ related to total and extractable soil concentrations as well as to $\mathrm{Pb}$ concentrations in the earthworms. These values, which are shown in Table 2, may give an indication of Pb toxicity in our soils, enable comparison with literature data and help identifying factors most affecting $\mathrm{Pb}$ toxicity. Because of the high earthworm mortality in the two most contaminated soils, no EC10 and EC50 values for weight loss could be determined. The 28-day LC50 for total Pb is much lower than the LC50 for soils spiked with solid $\mathrm{PbCO}_{3}$ and $\mathrm{PbS}$ observed by Davies et al. (2003a,b). The EC50 for earthworm reproduction in our study is much lower than the EC50s for the soils spiked with solid $\mathrm{PbCO}_{3}$ and $\mathrm{PbS}$ in the study of Davies et al. (2003b) and even lower than the EC50 for cocoon production for $\mathrm{Pb}$ freshly spiked into artificial soils in the study of Spurgeon et al. (1994). The latter studies used insoluble $\mathrm{Pb}$ forms which had a much lower availability than the $\mathrm{Pb}$ in our soils, explaining for the lower toxicity.

\subsection{The relationship between biological responses and physicochemical soil properties}

Significant negative relationships were found between earthworm survival and total and available $\mathrm{Pb}$ concentrations $(p<0.01)$ (Table 3). Significant positive relationships were observed between earthworm survival and $\mathrm{pH}$, Ca concentrations and CEC $(p<0.01)$, although $r$ values were lower than for $\mathrm{Pb}$ exposure levels. The significant correlation between earthworm survival and $\mathrm{pH}$ most likely is caused by the direct effect of (low) soil pH on earthworm

\section{Table 2}

LC50, EC10 and EC50 values (with corresponding 95\% confidence intervals) for the effects of $\mathrm{Pb}$ on the survival and reproduction of the earthworm Eisenia andrei exposed for 28 days to soils from a shooting range and different reference soils. Toxicity is related to total and available $\mathrm{Pb}$ concentrations in the soils as well as to concentrations accumulated in the earthworms. See Table 1 for soil properties and Fig. 1 for the $\mathrm{Pb}$ concentrations; Fig. 2 shows the earthworm responses.

\begin{tabular}{|c|c|c|c|}
\hline & LC50 & EC10 & EC50 \\
\hline Total Pb (mg/kg, dw) & $1603(1329-1939)$ & $1377\left(-^{\mathrm{a}}\right)$ & $1482(-)$ \\
\hline $\begin{array}{l}\text { Water extractable } \mathrm{Pb} \\
\quad(\mathrm{mg} / \mathrm{kg}, \mathrm{dw})\end{array}$ & $5.5(3.5-8.9)$ & $0.39(0.096-0.69)$ & $0.54(0.38-0.69)$ \\
\hline $\begin{array}{l}\mathrm{CaCl}_{2} \text { extractable } \mathrm{Pb} \\
\quad(\mathrm{mg} / \mathrm{kg}, \mathrm{dw})\end{array}$ & $98(53-181)$ & $0.44(-)$ & $2.2(-)$ \\
\hline Porewater $\mathrm{Pb}(\mathrm{mg} / \mathrm{L})$ & $5.1(3.0-8.7)$ & $99(8.6-189)$ & $130(102-158)$ \\
\hline $\begin{array}{l}\mathrm{Pb} \text { in earthworm } \\
\quad(\mathrm{mg} / \mathrm{kg}, \mathrm{dw})\end{array}$ & 852 (727-999) & $248(-)$ & $484(133-836)$ \\
\hline
\end{tabular}

\footnotetext{
${ }^{\text {a }}$ Very wide confidence intervals.
}

Table 3

Simple linear correlation coefficients relating the response of earthworms (Eisenia andrei) after 28 days exposure to the physicochemical properties of different shooting range field soils and reference soils. See Table 1 for soil properties, Fig. 1 for $\mathrm{Pb}$ concentrations and Fig. 2 for the earthworm responses.

\begin{tabular}{lcccc}
\hline $\begin{array}{l}\text { Soil physico-chemical } \\
\text { properties }\end{array}$ & \multicolumn{3}{c}{ Simple linear correlation coefficients $(r)$} \\
\cline { 2 - 5 } & Survival & Reproduction & $\begin{array}{l}\text { Weight } \\
\text { loss }\end{array}$ & $\begin{array}{l}\text { Pb in } \\
\text { earthworm }\end{array}$ \\
\hline $\mathrm{OM}$ & -0.045 & -0.15 & -0.084 & -0.13 \\
$\mathrm{pH}-\mathrm{H}_{2} \mathrm{O}$ & $0.50^{\mathrm{a}}$ & $0.67^{\mathrm{a}}$ & -0.28 & -0.20 \\
$\mathrm{pH}-0.01 \mathrm{M} \mathrm{CaCl}_{2}$ & $0.52^{\mathrm{a}}$ & $0.67^{\mathrm{a}}$ & $-0.31^{\mathrm{b}}$ & -0.27 \\
$\mathrm{DOC}$ & -0.046 & -0.24 & -0.12 & $-0.40^{\mathrm{a}}$ \\
$\mathrm{CEC}$ & $0.37^{\mathrm{a}}$ & $0.49^{\mathrm{a}}$ & $-0.38^{\mathrm{a}}$ & $-0.37^{\mathrm{a}}$ \\
$\mathrm{Ca}$ & $0.50^{\mathrm{a}}$ & $0.63^{\mathrm{a}}$ & $-0.38^{\mathrm{b}}$ & $-0.33^{\mathrm{b}}$ \\
$\mathrm{Fe}$ & $-0.27^{\mathrm{b}}$ & 0.090 & 0.088 & $0.44^{\mathrm{a}}$ \\
$\% \mathrm{Clay}$ & $0.31^{\mathrm{b}}$ & 0.29 & -0.13 & $-0.59^{\mathrm{a}}$ \\
\%Silt & $0.28^{\mathrm{b}}$ & $0.59^{\mathrm{a}}$ & -0.13 & $-0.43^{\mathrm{a}}$ \\
\%Sand & $-0.31^{\mathrm{b}}$ & $-0.42^{\mathrm{a}}$ & 0.14 & $0.55^{\mathrm{a}}$ \\
$\mathrm{Pb}-\mathrm{water}$ & $-0.79^{\mathrm{a}}$ & $-0.47^{\mathrm{a}}$ & $0.81^{\mathrm{a}}$ & $0.82^{\mathrm{a}}$ \\
Pb-0.01 M CaCl & $-0.83^{\mathrm{a}}$ & $-0.63^{\mathrm{a}}$ & $0.71^{\mathrm{a}}$ & $0.74^{\mathrm{a}}$ \\
Pb-porewater & $-0.78^{\mathrm{a}}$ & $-0.52^{\mathrm{a}}$ & $0.70^{\mathrm{a}}$ & $0.87^{\mathrm{a}}$ \\
Total Pb & $-0.68^{\mathrm{a}}$ & -0.21 & $0.70^{\mathrm{a}}$ & $0.97^{\mathrm{a}}$ \\
Total Cd & 0.18 & $0.50^{\mathrm{a}}$ & $-0.31^{\mathrm{b}}$ & 0.093 \\
Total $\mathrm{Zn}$ & 0.088 & $0.54^{\mathrm{a}}$ & -0.18 & 0.14 \\
Total Cu & -0.012 & $0.35^{\mathrm{b}}$ & -0.075 & $0.35^{\mathrm{b}}$ \\
\hline
\end{tabular}

a Correlation is significant at the 0.01 level (2-tailed).

b Correlation is significant at the 0.05 level (2-tailed).

survival (Spurgeon and Hopkin, 1996). Bradham et al. (2006) argued that the apparent correlation of earthworm survival with CEC may be caused by the strong inter-correlation between CEC and other exogenous variables such as $\mathrm{pH}$, and not by a direct effect of CEC (see e.g., Criel et al., 2008). Earthworm mortality was not significantly correlated with organic matter content or DOC concentration in the porewater, which agrees with other studies (Bradham et al., 2006; Janssen et al., 1997; Peijnenburg et al., 1999). Simple and stepwise regression analysis showed that the number of surviving of adult earthworms (SN) was well predicted on the basis of the porewater $\mathrm{Pb}$ concentrations, $\mathrm{CEC}$, silt and sand contents of the test soils (Table 4).

Reproduction expressed as juvenile numbers was significantly and positively correlated with $\mathrm{pH}, \mathrm{Ca}$, silt content, $\mathrm{Zn}, \mathrm{Cd}$ and $\mathrm{CEC}$, but significantly negative with sand content (Table 3 ). In all cases, except for $\mathrm{pH}, r$ values were low, suggesting these factors, although being significant, explain only a fraction of the variation in earthworm reproduction. The $\mathrm{pH}$ manipulated artificial soils showed an overall decrease in reproduction at $\mathrm{pH} 4.6$ and 5.9 in comparison to pH 6.8 (Fig. 2C). This is in agreement with the observations in artificial soils of Arnold et al. (2003), Currie et al. (2005) and Langdon et al. (2005). Earthworm reproduction was a greatly decreased in the field soils with $\mathrm{pH}$ values lower than 5.9 , such as F0, F1, F3 and B0 (Table 1; Fig. 2C). The correlation between reproduction and CEC was highly significant (Bradham et al., 2006), but CEC is directly related to soil pH (Sauvé, 2002; Bradham et al., 2006). In addition, Ca, Cd and $\mathrm{Zn}$ concentrations and silt content significantly and positively affected juvenile numbers, while a high sand content seemed to reduce juvenile numbers. Juvenile numbers were significantly and negatively correlated with water and $\mathrm{CaCl}_{2}$ extractable and porewater $\mathrm{Pb}$ but not with total $\mathrm{Pb}$ concentrations (Table 3). Juvenile numbers (JN) were well predicted based on the porewater $\mathrm{Pb}$ concentration, $\mathrm{Ca}$, silt, clay and $\mathrm{OM}$ contents and CEC of the test soils (Table 4).

Weight loss of earthworms was significantly and positively correlated with water extractable $\mathrm{Pb}$ concentrations, but negatively with CEC. The weight loss was significantly higher in soil R3 than in the control indicating that lower soil organic matter content could have adverse effect on earthworm growth. Other soil properties 
Table 4

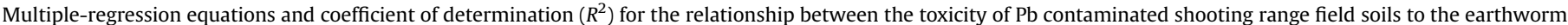
Eisenia andrei and physicochemical soil properties. See Table 1 for soil physicochemical properties, Fig. 1 for Pb concentrations and Fig. 2 for toxicity data.

\begin{tabular}{|c|c|c|}
\hline Endpoint & Multiple linear regression equation obtained & Statistics \\
\hline \multirow[t]{4}{*}{ Survival number (SN) } & $\begin{array}{l}\mathrm{SN}=-2.06\left(\log [\mathrm{Pb}]_{\mathrm{Total}}\right)-7.52(\log [\mathrm{Fe}])+2.08 \mathrm{pH}_{\mathrm{CaCl}_{2}}-3.53 \text { Clay }-2.63 \text { Silt }-2.90 \\
\mathrm{Sand}+322\end{array}$ & $p<0.001 ; R^{2}=0.840$ \\
\hline & $\begin{array}{l}\mathrm{SN}=-2.97\left(\log [\mathrm{Pb}]_{\text {Water extractable }}\right)-6.05(\log [\mathrm{Fe}])-1.82(\log [\mathrm{Ca}])-0.495 \text { Clay }+0.362 \\
\text { Silt }+0.925 \mathrm{pH}_{\mathrm{H}_{2} \mathrm{O}}+27.7\end{array}$ & $p<0.05 ; R^{2}=0.841$ \\
\hline & $\mathrm{SN}=-2.04\left(\log [\mathrm{Pb}]_{\mathrm{CaCl}_{2} \text { extractable }}\right)-0.510 \mathrm{pH}_{\mathrm{H}_{2} \mathrm{O}}+11.4$ & $p<0.05 ; R^{2}=0.696$ \\
\hline & $\mathrm{SN}=-3.57\left(\log [\mathrm{Pb}]_{\text {Porewater }}\right)-0.411 \mathrm{CEC}+0.726$ Silt +0.439 Sand -25.3 & $p<0.001 ; R^{2}=0.851$ \\
\hline \multirow[t]{4}{*}{ Juvenile number (JN) } & $\mathrm{JN}=-6.81\left(\log [\mathrm{Pb}]_{\text {Total }}\right)+26.9(\log [\mathrm{Fe}])+2.62$ Silt $+3.12 \mathrm{CEC}-7.34 \mathrm{OM}-69.0$ & $p<0.001 ; R^{2}=0.904$ \\
\hline & $\mathrm{JN}=-5.07\left(\log [\mathrm{Pb}]_{\text {Water extractable }}\right)+23.0(\log [\mathrm{Fe}])+2.57$ Silt $+2.84 \mathrm{CEC}-6.84 \mathrm{OM}-73.1$ & $p<0.01 ; R^{2}=0.893$ \\
\hline & $\mathrm{JN}=-9.40\left(\log [\mathrm{Pb}]_{\mathrm{CaCl}_{2} \text { extractable }}\right)+35.8(\log [\mathrm{Fe}])+3.36 \mathrm{Silt}-2.56 \mathrm{OM}-134$ & $p<0.001 ; R^{2}=0.839$ \\
\hline & $\mathrm{JN}=-4.28\left(\log [\mathrm{Pb}]_{\text {Porewater }}\right)-31.8(\log [\mathrm{Ca}])+3.09$ Silt $-10.2 \mathrm{OM}+6.70 \mathrm{CEC}-1.72$ Clay +104 & $p<0.05 ; R^{2}=0.910$ \\
\hline \multirow[t]{4}{*}{ Weight loss (WL, \%) } & $\mathrm{WL}=24.2\left(\log [\mathrm{Pb}]_{\text {Total }}\right)+1.92$ Clay -1.81 Silt -49.2 & $p<0.001 ; R^{2}=0.812$ \\
\hline & $\mathrm{WL}=12.0\left(\log [\mathrm{Pb}]_{\text {Water extractable }}\right)+24.9$ & $p<0.001 ; R^{2}=0.645$ \\
\hline & $\mathrm{WL}=13.6\left(\log [\mathrm{Pb}]_{\mathrm{CaCl}_{2} \text { extractable }}\right)+5.87 \mathrm{pH}_{\mathrm{CaCl}_{2}}+1.78$ Clay +0.766 Sand -86.3 & $p<0.05 ; R^{2}=0.706$ \\
\hline & $\mathrm{WL}=17.0\left(\log [\mathrm{Pb}]_{\text {Porewater }}\right)+1.72 \mathrm{CEC}+3.30$ Clay +1.12 Sand -140 & $p<0.001 ; R^{2}=0.817$ \\
\hline \multirow{4}{*}{$\begin{array}{l}\mathrm{Pb} \text { concentration in } \\
\text { earthworms } \\
\left(C_{\mathrm{w}}, \mathrm{mg} / \mathrm{kg} \mathrm{dw}\right)\end{array}$} & $\log C_{\mathrm{w}}=0.878\left(\log [\mathrm{Pb}]_{\text {Total }}\right)-0.0247$ Silt +0.280 & $p<0.01 ; R^{2}=0.968$ \\
\hline & $\log C W=0.546\left(\log [\mathrm{Pb}]_{\text {Water extractable }}\right)+0.364(\log [\mathrm{Fe}])-0.001$ DOC -0.020 Clay +1.78 & $p<0.01 ; R^{2}=0.946$ \\
\hline & $\begin{array}{l}\log C_{\mathrm{w}}=0.548\left(\log [\mathrm{Pb}]_{\mathrm{CaCl}_{2} \text { extractable }}\right)+1.80(\log [\mathrm{Ca}])+0.619(\log [\mathrm{Fe}])-0.000451 \\
\mathrm{DOC}-0.124 \mathrm{CEC}-3.83\end{array}$ & $p<0.01 ; R^{2}=0.963$ \\
\hline & $\log C_{\mathrm{w}}=0.644\left(\log [\mathrm{Pb}]_{\text {Porewater }}\right)+0.800(\log [\mathrm{Ca}])-1.31$ & $p<0.001 ; R^{2}=0.908$ \\
\hline
\end{tabular}

hardly affected earthworm weight loss, which agrees with other studies (Van Gestel et al., 1992; Currie et al., 2005). Earthworm weight loss (WL) was well predicted by porewater Pb concentrations, CEC, clay and sand contents of the test soils (Table 4).

$\mathrm{Pb}$ concentrations in the earthworms were positively correlated with total and available $\mathrm{Pb}$ concentrations in soil, sand content and Fe, but negatively with clay and silt content, DOC and CEC (Table 3), with the latter factors explaining less of the variation in earthworm $\mathrm{Pb}$ concentrations. $\mathrm{Pb}$ concentrations in the earthworms were well predicted by total $\mathrm{Pb}$ concentrations and silt contents of the soils (Table 4). Grelle and Descamps (1998) also found that soil total Pb concentration was a better predictor of earthworm body burden than $\mathrm{CaCl}_{2}$-extractable $\mathrm{Pb}$ levels. Previous studies demonstrated that soil physicochemical properties have a significant impact on $\mathrm{Pb}$ uptake by E. andrei (Spurgeon and Hopkin, 1995; Peijnenburg et al., 1999; Bradham et al., 2006; Smith et al., 2012). For example, soil pH has been suggested as the most important factor for controlling the bioavailability of $\mathrm{Pb}$ in soil, followed by organic matter content (Thomas, 1997; Peijnenburg et al., 1999). In the present study, the effect of $\mathrm{pH}$ was weaker for internal $\mathrm{Pb}$ than for reproduction (Table 3). This was not in agreement with the results observed by Peijnenburg et al. (1999), Langdon et al. (2005) and Bradham et al. (2006). Internal Pb concentrations did not correlate with soil OM content, but they significantly and negatively correlated with DOC level in the porewater. In addition, internal $\mathrm{Pb}$ was negatively correlated with clay content and silt content but positively with $\mathrm{Fe}$ and sand content, which all have been shown also by others to be modifying Pb uptake by earworms (Janssen et al., 1997; Peijnenburg et al., 1999; Basta et al., 2005).

\section{Conclusion}

Most shooting range soils were contaminated with $\mathrm{Pb}$ at concentrations exceeding the background levels in Dutch soils. The forest soils had the highest total, water and $\mathrm{CaCl}_{2}$ extractable and porewater $\mathrm{Pb}$ concentrations, but also the lowest $\mathrm{pH}$. After 28-day exposure, mortality of adult earthworms occurred in the two most contaminated soils at total $\mathrm{Pb}$ concentrations $\geq 2153 \mathrm{mg} / \mathrm{kg} \mathrm{dw}$. Soil $\mathrm{pH}$ and organic matter contents significantly affected juvenile numbers, but did not affect mortality, weight loss and internal $\mathrm{Pb}$ concentrations in the earthworms. At soil total $\mathrm{Pb}$ concentrations $>2000 \mathrm{mg} / \mathrm{kg}$, earthworm weight loss significantly increased, while reproduction significantly decreased. At porewater $\mathrm{Pb}$ concentrations $>0.028 \mathrm{mg} / \mathrm{L}$ juvenile numbers were significantly lower. Also $\mathrm{pH}<5.9$ significantly reduced juvenile numbers. Earthworm survival, growth and reproduction as well as Pb uptake in the earthworms were correlated with total or available $\mathrm{Pb}$ concentrations and also affected by different soil properties, such as $\mathrm{pH}, \mathrm{CEC}$ and $\mathrm{OM}$ and sand content. This study showed that a combination of physicochemical and biological assays may help determining lead toxicity and bioavailability in earthworms exposed to shooting range field soils.

\section{Acknowledgement}

This project was funded by a visitor's grant (number 040.11.222) from The Netherlands Science Foundation (NWO) and by the National Natural Science Foundation of China under Grant No. 41271502.

\section{References}

Ahmad, M., Lee, S.S., Moon, D.H., Yang, J.E., Ok, Y.S., 2011. A review of environmental contamination and remediation strategies for heavy metals at shooting range soils. In: Malik, A., Grohmann, E. (Eds.), Environmental Protection Strategies for Sustainable Development. Springer, pp. 437-452.

Alexander, M., 2000. Aging, bioavailability, and overestimation of risk from environmental pollutants. Environ. Sci. Technol. 34, 4259-4265.

Alvarenga, P., Palma, P., de Varennes, A., Cunha-Queda, A.C., 2012. A contribution towards the risk assessment of soils from the São Domingos Mine (Portugal): chemical, microbial and ecotoxicological indicators. Environ. Pollut. 161, 50-56.

Antunes, S.C., Castro, B.B., Pereira, R., Goncalves, F., 2008. Contribution for tier 1 of the ecological risk assessment of Cunha Baixa uranium mine (Central Portugal): II. Soil ecotoxicological screening. Sci. Total Environ. 390, 387-395.

Arnold, R.E., Hodson, M.E., 2007. Effect of time and mode of depuration on tissue copper concentrations of the earthworms Eisenia andrei, Lumbricus rubellus and Lumbricus terrestris. Environ. Pollut. 148, 21-30.

Arnold, R.E., Hodson, M.E., Black, S., Davies, N.A., 2003. The influence of mineral solubility and soil solution concentration on the toxicity of copper to Eisenia fetida Savigny. Pedobiologia 47, 622-632.

Basta, N., Tabatabai, M., 1992. Effect of cropping systems on adsorption of metals by soils: II. Effect of pH. Soil Sci. 153, 195-204.

Basta, N.T., Ryan, J.A., Chaney, R.L., 2005. Trace element chemistry in residualtreated soil: key concepts and metal bioavailability. J. Environ. Qual. 34, 49-63.

Booth, L., Palasz, F., Darling, C., Lanno, R., Wickstrom, M., 2003. The effect of leadcontaminated soil from Canadian prairie skeet ranges on the neutral red retention assay and fecundity in the earthworm Eisenia fetida. Environ. Toxicol. Chem. 22, 2446-2453.

Bradham, K.D., Dayton, E.A., Basta, N.T., Schroder, J., Payton, M., Lanno, R.P., 2006. Effect of soil properties on lead bioavailability and toxicity to earthworms. Environ. Toxicol. Chem. 25, 769-775. 
Cao, X.D., Ma, L.Q., Chen, M., Hardison, D.W., Harris, W.G., 2003. Lead transformation and distribution in the soils of shooting ranges in Florida, USA. Sci. Total Environ. 307, 179-189.

Cook, N., Hendershot, W.H., 1996. The problem of establishing ecologically based soil quality criteria: the case of lead. Can. J. Soil Sci. 76, 335-342.

Criel, P., Lock, K., Van Eeckhout, H., Oorts, K., Smolders, E., Janssen, C.R., 2008. Influence of soil properties on copper toxicity for two soil invertebrates. Environ. Toxicol. Chem. 27, 1748-1755.

Currie, M., Hodson, M.E., Arnold, R.E., Langdon, C.J., 2005. Single versus multiple occupancy - effects on toxicity parameters measured on Eisenia fetida in lead nitrate-treated soil. Environ. Toxicol. Chem. 24, 110-116.

Davies, B.E., 1992. Interrelationships between soil properties and the uptake of cadmium, copper, lead and zinc from contaminated soils by radish (Raphanus sativus L). Water Air Soil Pollut. 63, 331-342.

Davies, N.A., Hodson, M.E., Black, S., 2003a. The influence of time on lead toxicity and bioaccumulation determined by the OECD earthworm toxicity test. Environ. Pollut. 121, 55-61.

Davies, N.A., Hodson, M.E., Black, S., 2003b. Is the OECD acute worm toxicity test environmentally relevant? the effect of mineral form on calculated lead toxicity. Environ. Pollut. 121, 49-54.

Dohrmann, R., 2006. Cation exchange capacity methodology II: a modified silverthiourea method. Appl. Clay Sci. 34, 38-46.

Edwards, C., 1988. Breakdown of animal, vegetable, and industrial organic wastes by earthworms. In: Edwards, C., Neuhauser, E. (Eds.), Earthworms in Waste and Environmental Management. SPB Academic The Hague, The Netherlands, pp. $21-31$.

Edwards, C., Bohlen, P., 1996. Biology and Ecology of Earthworms, third ed. Chapman \& Hall, London, UK.

Ehlers, L.J., Luthy, R.G., 2003. Contaminant bioavailability in soil and sediment. Environ. Sci. Technol. 37, 295A-302A.

Emersen, R., 1994. Contamination of Soil from Gun Shot: St. Thomas Gun Club (1993). Standards Development Branch, Phytotoxicology Section. Ontario Ministry of Environment and Energy, Brampton, ON, Canada.

Farrah, H., Pickering, W.F., 1979. pH effects in the adsorption of heavy metal ions by clays. Chem. Geol. 25, 317-326.

Grelle, C., Descamps, M., 1998. Heavy metal accumulation by Eisenia fetida and its effects on glutathione-S-transferase activity. Pedobiologia 42, 289-297.

Haanstra, L., Doelman, P., Oude Voshaar, J.H., 1985. The use of sigmoidal dose response curves in soil ecotoxicological research. Plant Soil 84, 293-297.

Hamilton, M.A., Russo, R.C., Thurston, R.V., 1977. Trimmed Spearman-Karber method for estimating median lethal concentrations in toxicity bioassays. Environ. Sci. Technol. 11, 714-719.

Harmsen, J., 2007. Measuring bioavailability: from a scientific approach to standard methods. J. Environ. Qual. 36, 1420-1428.

Heier, L.S., Meland, S., Ljones, M., Salbu, B., Stromseng, A.E., 2010. Short-term temporal variations in speciation of $\mathrm{Pb}, \mathrm{Cu}, \mathrm{Zn}$ and $\mathrm{Sb}$ in a shooting range runoff stream. Sci. Total Environ. 408, 2409-2417.

Hobbelen, P.H.F., Koolhaas, J.E., van Gestel, C.A.M., 2004. Risk assessment of heavy metal pollution for detritivores in floodplain soils in the Biesbosch, the Netherlands, taking bioavailability into account. Environ. Pollut. 129, 409-419.

Houba, V.J.G., Lexmond, T.M., Novozamsky, I., van der Lee, J.J., 1996. State of the art and future developments in soil analysis for bioavailability assessment. Sci. Total Environ. 178, 21-28.

Howard, P.J.A., Howard, D.M., 1990. Use of organic carbon and loss-on-ignition to estimate soil organic matter in different soil types and horizons. Biol. Fertil. Soils 9, 306-310.

ISO, I., 1999. Soil Quality - Inhibition of Reproduction of Collembola (Folsomia candida) by Soil Pollutants. ISO 11267. International Standardization Organization, Geneva.

Janssen, R.P.T., Posthuma, L., Baerselman, R., Den Hollander, H.A., van Veen, R.P.M., Peijnenburg, W.J.G.M., 1997. Equilibrium partitioning of heavy metals in Dutch field soils. 2. Prediction of metal accumulation in earthworms. Environ. Toxicol. Chem. 16, 2479-2488.

Johnson, C.A., Moench, H., Wersin, P., Kugler, P., Wenger, C., 2005. Solubility of antimony and other elements in samples taken from shooting ranges. J. Environ. Qual. 34, 248-254.

Jorgensen, S., Willems, M., 1987. The fate of lead in soils: the transformation of lead pellets in shooting range soils. Ambio 16, 11-15.

Kabata-Pendias, A., Pendias, H., 1992. Trace Elements in Soils and Plants, second ed. CRC, Boca Raton, FL, USA.

Konert, M., Vandenberghe, J., 1997. Comparison of laser grain size analysis with pipette and sieve analysis: a solution for the underestimation of the clay fraction. Sedimentology 44, 523-535.

Langdon, C.J., Hodson, M.E., Arnold, R.E., Black, S., 2005. Survival, Pb-uptake and behaviour of three species of earthworm in Pb treated soils determined using an OECD-style toxicity test and a soil avoidance test. Environ. Pollut. 138, 368375.

Lin, Z.X., 1996. Secondary mineral phases of metallic lead in soils of shooting ranges from Orebro County, Sweden. Environ. Geol. 27, 370-375.

Lock, K., Waegeneers, N., Smolders, E., Criel, P., Van Eeckhout, H., Janssen, C.R., 2006. Effect of leaching and aging on the bioavailability of lead to the springtail Folsomia candida. Environ. Toxicol. Chem. 25, 2006-2010.

Loureiro, S., Soares, A.M.V.M., Nogueira, A.J.A., 2005. Terrestrial avoidance behaviour tests as screening tool to assess soil contamination. Environ. Pollut. 138, $121-131$.
Morgan, A., Morgan, J., Turner, M., Winters, C., Yarwood, A., 1993. Metal relationships of earthworms. In: Dallinger, R., Rainbow, P. (Eds.), Ecotoxicology of Metals in Invertebrates. Lewis, Boca Ration, FL, USA, pp. 333-358.

Mozafar, A., Ruh, R., Klingel, P., Gamper, H., Egli, S., Frossard, E., 2002. Effect of heavy metal contaminated shooting range soils on mycorrhizal colonization of roots and metal uptake by leek. Environ. Monit. Assess. 79, 177-191.

Nahmani, J., Hodson, M.E., Black, S., 2007. A review of studies performed to assess metal uptake by earthworms. Environ. Pollut. 145, 402-424.

OECD, 1984. Guidelines for the Testing of Chemicals No. 207. Earthworm Acute Toxicity. Organization for Economic Cooperation and Development, Paris.

OECD, 2004. Guideline for the Testing of Chemicals No. 222. Earthworm Reproduction Test (Eisenia fetida/Eisenia andrei). Organization for Economic Cooperation and Development, Paris.

Peijnenburg, W., Baerselman, R., de Groot, A.C., Jager, T., Posthuma, L., Van Veen, R.P.M., 1999. Relating environmental availability to bioavailability: soiltype-dependent metal accumulation in the oligochaete Eisenia andrei. Ecotoxicol. Environ. Saf. 44, 294-310.

Quevauviller, P., 1998. Operationally defined extraction procedures for soil and sediment analysis - I. Stand. Trac-trends Anal. Chem. 17, 289-298.

Reinecke, A.J., Maboeta, M.S., Reinecke, S.A., 1997. Stimulating effects of low lead concentrations on growth and cocoon production of Eisenia fetida (Oligochaeta). S. Afr. J. Zool. 32, 72-75.

Reinecke, A.J., Reinecke, S.A., 1996. The influence of heavy metals on the growth and reproduction of the compost worm Eisenia fetida (Oligochaeta). Pedobiologia 40, 439-448.

Rieuwerts, J.S., Ashmore, M.R., Farago, M.E., Thornton, I., 2006. The influence of soil characteristics on the extractability of $\mathrm{Cd}, \mathrm{Pb}$ and $\mathrm{Zn}$ in upland and moorland soils. Sci. Total Environ. 366, 864-875.

Robinson, B.H., Bischofberger, S., Stoll, A., Schroer, D., Furrer, G., Roulier, S., Gruenwald, A., Attinger, W., Schulin, R., 2008. Plant uptake of trace elements on a Swiss military shooting range: uptake pathways and land management implications. Environ. Pollut. 153, 668-676.

Sauvé, S., 2002. Speciation of metals in soils. In: Allen, H.E. (Ed.), Bioavailability of Metals in Terrestrial Ecosystems: Importance of Partitioning for Bioavailability to Invertebrates, Microbes, and Plants. SETAC Press, Pensacola, FL, pp. 7-37.

Semple, K.T., Doick, K.J., Jones, K.C., Burauel, P., Craven, A., Harms, H., 2004. Defining bioavailability and bioaccessibility of contaminated soil and sediment is complicated. Environ. Sci. Technol. 38, 228A-231A.

Singh, S.P., Tack, F.M.G., Verloo, M.G., 1996. Extractability and bioavailability of heavy metals in surface soils derived from dredged sediments. Chem. Speciat. Bioavailab. 8, 105-110.

Smith, B.A., Greenberg, B., Stephenson, G.L., 2012. Bioavailability of copper and zinc in mining soils. Arch. Environ. Contam. Toxicol. 62, 1-12.

Smolders, E., Oorts, K., van Sprang, P., Schoeters, I., Janssen, C.R., McGrath, S.P. McLaughlin, M.J., 2009. Toxicity of trace metals in soil as affected by soil type and aging after contamination using calibrated bioavailability models to set ecological soil standards. Environ. Toxicol. Chem. 28, 1633-1642.

Sorvari, J., 2007. Environmental risks at Finnish shooting ranges - a case study Hum. Ecol. Risk Assess. 13, 1111-1146.

Sorvari, J., Antikainen, R., Pyy, O., 2006. Environmental contamination at Finnish shooting ranges - the scope of the problem and management options. Sci. Total Environ. 366, 21-31.

Spurgeon, D.J., Hopkin, S.P., 1995. Extrapolation of the laboratory-based OECD earthworm toxicity test to metal-contaminated field sites. Ecotoxicology 4, 190-205.

Spurgeon, D.J., Hopkin, S.P., 1996. Effects of variations of the organic matter content and $\mathrm{pH}$ of soils on the availability and toxicity of zinc to the earthworm Eisenia fetida. Pedobiologia 40, 80-96.

Spurgeon, D.J., Hopkin, S.P., Jones, D.T., 1994. Effects of cadmium, copper, lead and zinc on growth, reproduction and survival of the earthworm Eisenia fetida (Savigny) - assessing the environmental impact of point-source metal contamination in terrestrial ecosystems. Environ. Pollut. 84, 123-130.

Svendsen, C., Meharg, A.A., Freestone, P., Weeks, J.M., 1996. Use of an earthworm lysosomal biomarker for the ecological assessment of pollution from an industrial plastics fire. Appl. Soil Ecol. 3, 99-107.

Terhivuo, J., Pankakoski, E., Hyvarinen, H., Koivisto, I., 1994. Pb uptake by ecologically dissimilar earthworm (Lumbricidae) species near lead smelter in south Finland. Environ. Pollut. 85, 87-96.

Thomas, V.G., 1997. The environmental and ethical implications of lead shot contamination of rural lands in North America. J. Agric. Environ. Ethics 10 $41-54$.

USEPA, 2001. Best Management Practices for Lead at Outdoor Shooting Range (EPA/ 902-B-01-001). RCRA Compliance Branch, New York.

Van Brummelen, T.C., Van Gestel, C.A.M., Verweij, R.A., 1996. Long-term toxicity of five polycyclic aromatic hydrocarbons to the terrestrial isopods Oniscus asellus and Porcellio scaber. Environ. Toxicol. Chem. 15, 1199-1210.

Van Gestel, C.A.M., McGrath, S.P., Smolders, E., Ortiz, M.D., Borgman, E., Verweij, R.A., Buekers, J., Oorts, K., 2012. Effect of long-term equilibration on the toxicity of molybdenum to soil organisms. Environ. Pollut. 162, 1-7.

Van Gestel, C.A.M., Van Breemen, E.M.D., Baerselman, R., 1992. Influence of environmental conditions on the growth and reproduction of the earthworm Eisenia andrei in an artificial soil substrate. Pedobiologia 36, 109-120.

Van Gestel, C.A.M., van der Waarde, J.J., Derksen, J.G.M., van der Hoek, E.E., Veul, M., Bouwens, S., Rusch, B., Kronenburg, R., Stokman, G.N.M., 2001. The 
use of acute and chronic bioassays to determine the ecological risk and bioremediation efficiency of oil-polluted soils. Environ. Toxicol. Chem. 20, 1438-1449.

Van Gestel, C.A.M., Vandis, W.A., Vanbreemen, E.M., Sparenburg, P.M., 1989 Development of a standardized reproduction toxicity test with the earthworm species Eisenia fetida andrei using copper, pentachlorophenol, and 2,4-dichloroaniline. Ecotoxicol. Environ. Saf. 18, 305-312.
Van Vleek, B., Amarasiriwardena, D., Xing, B., 2010. Investigation of distribution of soil antimony using sequential extraction and antimony complexed to soilderived humic acids molar mass fractions extracted from various depths in a shooting range soil. Microchem. J. 97, 68-73.

Vegter, J., 1995. Soil protection in the Netherlands. In: Salomons, W., Förstner, U., Mader, P. (Eds.), Heavy Metals-problems and Solutions. Springer-Verlag, Berlin, pp. 79-100. 